\title{
Posttransplant Lymphoproliferative Disorder of the Central Nervous System
}

\author{
Christian Kempf ${ }^{a}$ Marianne Tinguely ${ }^{b, c}$ Elisabeth J. Rushing ${ }^{a}$ \\ Institutes of a Neuropathology and ${ }^{\mathrm{b}}$ Surgical Pathology, University Hospital Zurich, and ${ }^{\mathrm{C}}$ Kempf und Pfaltz, \\ Histologische Diagnostik, Zurich, Switzerland
}

\section{Key Words}

Posttransplant lymphoproliferative disorder · Central

nervous system $\cdot$ Immunosuppressive therapy

\begin{abstract}
Posttransplant lymphoproliferative disorder (PTLD) involves uncommon, severe complications following the transplantation of solid organs, bone marrow and stem cells. Despite comprising mainly lymphoid proliferations that are predominantly driven by lymphotropic Epstein-Barr virus (EBV) infections, PTLD often displays substantial morphologic heterogeneity that can pose diagnostic challenges. With the steady increase in transplantations accompanied by potent immunosuppressive therapy, it is important to heighten awareness of this entity among clinicians and pathologists. In comparison to systemic PTLD, cases that primarily manifest in the central nervous system (CNS) are reported to be more severe and to exhibit unique characteristics. So far, only isolated cases and small series have been reported describing CNS involvement in PTLD. In this article, we review the current knowledge, focusing on the histopathological features of primary CNS lymphoproliferative disorders following organ transplantation.

Copyright $\odot 2013$ S. Karger AG, Basel
\end{abstract}

\section{Introduction}

In the early 1940s, Gibson and Medawar [1] provided the first experimental evidence that homograft tissue rejection is an immune-mediated process. Based on this landmark collaboration, the need for immune suppression following organ transplantation was firmly established and the era of immunomodulatory drug therapy was launched. Today, treatment with immunosuppressive agents has evolved into sophisticated regimes with optimized pharmacokinetics and pharmacodynamics to minimize the chances of allograft rejection. Nevertheless, immunosuppressive therapy is a double-edged sword that puts the host at risk for a multitude of infectious, neoplastic and vascular diseases, including posttransplant lymphoproliferative disorder (PTLD). Systemic PTLD can display morphological diversity, often resembling diffuse large B cell lymphoma, whereas isolated central nervous system (CNS) PTLD is usually monomorphic [2]. Rarely, $T$ cell PTLD is reported that is negative for Epstein-Barr virus (EBV) and behaves even more aggressively [3]. It typically develops later than B cell PTLD, and patients are less likely to respond to a reduction of immunosuppressive drugs [3]. Until recently, PTLD has been considered

\section{KARGER}

E-Mail karger@karger.com www.karger.com/pat
(C) 2013 S. Karger AG, Basel

1015-2008/13/0806-0310\$38.00/0
Elisabeth J. Rushing, MD

Institute of Neuropathology, University Hospital Zurich

Schmelzbergstrasse 12

CH-8091 Zürich (Switzerland)

E-Mail elisabethjane.rushing@usz.ch 
a rare disease. Because of the upward trend of organ transplantation over the last 2 decades and the attendant immunosuppression-associated complications, PTLD is emerging as an increasingly important clinical entity. Still today, evidence-based treatment protocols are lacking and there is still no consensus regarding therapeutic regimens $[4,5]$. In many transplant centers, weekly EBVDNA analysis via polymerase chain reaction is carried out to monitor the viral load and facilitate preemptive therapy with either reduction in the dose of immunosuppressive agents or anti-CD20 immunotherapy. Currently, innovative triple-drug regimens are favored because of their dual antiproliferative and immunosuppressive properties [5]. Our review focuses on the current literature on PTLD with the primary focus on isolated CNS manifestations. The clinicopathologic findings of this subgroup of PTLD have not yet been rigorously described and little experimental data are available to explain the pathogenetic basis for its distinctive features. What has emerged from the existing literature is that primary CNS PTLD is distinctly more aggressive than its systemic counterpart [6].

\section{Epidemiology}

In 1968, Doak et al. [7] published the first case-report of systemic lymphoproliferative disorder following renal transplantation, only a few years after the introduction of immunosuppressive therapy for transplant recipients [8]. Shortly thereafter, Schneck and Penn [9] documented the first isolated case of cerebral PTLD following kidney transplantation. Subsequently, there has been a considerable increase in the annual incidence of PTLD, ranging from 1 to $10 \%$ depending on the organ transplanted [10]. A study by Walker et al. [11] reported the PTLD in 6.2\% of patients after lung transplantation, in 5.2\% after kidney and pancreas transplantation, in $2.0 \%$ after heart transplantation and in $1.4 \%$ after liver transplantation. The difference in the frequency of PTLD among these groups has been attributed to the organ-specific immunosuppressive regimens.

Primary CNS PTLD has been observed in 5-15\% of all PTLD cases [6], much more frequent than CNS presentations in patients with de novo non-Hodgkin lymphoma. Whereas the highest incidence of systemic PTLD occurs within the first year after transplantation, with a median onset of 6 months [6], isolated CNS PTLD tends to appear much later. In a recent study on CNS PTLD, Castellano-Sanchez et al. [6] reported onset latencies ranging from 3 to 131 months (mean, 31 months) after transplantation. The general incidence of PTLD has increased dramatically due to several reasons, with the increase in transplantations being for the most obvious explanation, followed by the considerably longer survival of transplant patients. In addition, the development of highly potent immunosuppressive drugs appears to play a significant role in the rise of PTLD. Of particular relevance to the risk of developing PTLD is the total amount of immunosuppression over time in addition to the individual drug selection. Apart from dosage, certain combinations of medications, such as tacrolimus and OKT3, have been reported to substantially potentiate the risk of PTLD [12]. Moreover, there is a 4 -fold higher incidence of developing PTLD in children compared to adults [13]. This is commonly explained by EBV seronegativity in the pediatric population before transplantation compared to the adult population, where $90 \%$ are considered to carry a latent EBV infection. Thus the seronegative pediatric patients acquire the virus with the transplanted organ, which seems to enhance the likelihood of developing PTLD [13]; which organ is transplanted is also a factor [11]. Besides the EBV status of the host, allograft type and age are additional variables implicated in the development of PTLD. The type and dosage of the immunotherapy regime, multiorgan transplantation, concurrent human cytomegalovirus, hepatitis $\mathrm{C}$ infection and specific cytokines are other factors that modulate EBV replication $[14,15]$. Also associated with a higher PTLD risk are the presence of a pretransplant malignancy, white race, male sex, therapy with calcineurin inhibitors, monoclonal antibodies such as anti-CD3 (OKT3) and antithymocyte globulin, tacrolimus and cyclosporine [15].

\section{Pathogenesis and Pathobiology}

As noted, the vast majority ( $80 \%$ ) of CNS PTLD cases are associated with EBV, also called human herpesvirus 4 (HHV-4), a double-stranded DNA virus of the $\gamma$-herpesvirus family. In early-onset CNS PTLD, almost $100 \%$ of cases arise in the setting of EBV infection, latent, acute or acquired from the allograft. Two distinct stages are recognized in EBV infection: the lytic phase, characterized by active viral replication and the expression of all EBV proteins, which may lead to cell death and release of virions. During the latency phase, B cells are infected via their CD21 receptor and persist in the cell without lysis [16, 17]. In EBV-associated PTLD, EBV early RNA, EBV latent membrane protein and EBV DNA are present [18- 
20]. The underlying molecular pathogenesis is based on an uncontrolled proliferation of EBV-infected B cells after immunosuppressive therapy. Active EBV infection is usually acquired during childhood or adolescence, and eventually enters a latency phase, with viral DNA persisting as a so-called episome in the nuclei of B lymphocytes [21]. EBV encodes a series of proteins including the EBV nuclear antigens, EBNA1 (DNA-binding nuclear phosphoprotein), EBNA2 (transcriptional coactivator), EBNA3A-C, EBNA-LP and the latent membrane protein LMP1, LMP2A and LMP2B. EBV-encoded nontranslational RNAs are then transcribed [20-22] and infected B cells differentiate into memory cells and EBV inclusions remain, with most of the infected cells cleared by cytotoxic $\mathrm{T}$ cells. Immunosuppressive therapy following transplantation unleashes a chain of events leading to decreased $\mathrm{T}$ cell functions, uncontrolled viral replication, expansion of EBV-infected B cells, EBV oncogene expression, proliferation and, ultimately, malignant transformation. Other molecular factors reported to abet the development of PTLD are microsatellite instability, DNA hypermethylation and somatic mutations of proto-oncogenes as well as molecular alterations of BCL-6, TP53 and c-MYC genes [17]. The BCL-6 gene product is a transcriptional repressor $[23,24]$, with rearrangement rarely seen in PTLD; however, somatic hypermutations are documented in several cases [25]. The TP53 gene encodes a tumor suppressor and has been reported to be deleted in a small proportion of monomorphic PTLD [26]. Additional evidence suggests that deregulation of the protooncogene c-MYC, located on chromosome $8 \mathrm{q} 24$, is a frequent target of chromosomal breaks that contribute to early pathomechanisms in the development of PTLD [27]. Deregulation of c-MYC is regarded as a pivotal event in the pathogenesis of PTLD. c-MYC directly controls DNA replication and plays a major role in regulating $B$ cell proliferation [28]. It has also been reported that cMYC-CD19 gene expression synergizes to trigger B cell transformation and lymphoma progression [29]. Based on the induction of hyperphosphorylation, c-MYC is stabilized and regulates a genetic pathway governed by cyclin D2 overexpression that enhances lymphomagenesis. Accordingly, agents that block the amplification of CD19 (Src-family kinase) or inhibit Ras-ERK activity might improve existing antilymphoproliferative therapies [29]. Experiments have demonstrated that the oncogenes EBNA1 and LMP1 play a major role in the transformation of replicative EBV into oncogenic EBV in fibroblasts [30]. LMP1 is considered to represent one of the major transforming factors of EBV. As an integral membrane protein expressed on the surface of infected B lymphocytes, LMP1 mimics CD40 receptors involved in the proliferation and survival signaling in B cells [31]. This is achieved by binding the cytoplasmic signal transduction molecule TRAF (TNF receptor-associated factors), which activates certain cellular signaling pathways (NF- $\kappa B$, JNK1, AP1, Jak3/STAT and others). These signaling cascades lead to enhanced expression of the antiapoptotic factors BCL-2 and A20, c-MYC and B cell adhesion molecules [32]. Furthermore, transgenic mice expressing LMP1 are known to develop lymphomas after the upregulation of BCL-2 and A20 gene [33]. However, given the large number of organ recipients and the fact that only a small percentage of patients who are seropositive for EBV develop PTLD, it is apparent that there are also other factors which contribute to the pathogenesis of monoclonal B cell proliferation. Epigenetic modifications of tumor suppressor and oncogenes represent further candidates discussed in the pathogenesis of PTLD. Among the epigenetic factors implicated in PTLD are the hypermethylation of serine-threonine kinase DAP- $k$, which is involved in apoptotic signaling and the DNA repair gene $\mathrm{O}^{6}$-methylguanine-DNA methyl-transferase and is reported to be methylated in $75 \%$ of polymorphic PTLD and in $93 \%$ of monomorphic PTLD [27, 34]. Further genes known to be hypermethylated in PTLD are tumor suppressor genes P73 and P16 and the SHP1 gene, whose gene products inhibit the JAKs/STATs pathway and thereby slow B lymphocyte proliferation [27, 35, 36]. In addition to the frequent association with EBV infection, PTLD shares other features common to immunodeficiency-related lymphomas. The molecular pathogenesis and underlying cause of EBV seronegative PTLD are still unclear, with other viral agents being considered. Epidemiological studies point to hepatitis $C$ virus and simian virus as playing a possible role $[14,15,27]$. Of interest, human herpesvirus 8 (HHV-8) gene products possess homologies to human genes involved in antiapoptotic signaling, cell proliferation and angiogenesis [37].

\section{Clinical Manifestations and Diagnostic Aspects}

Patients with CNS PTLD present with a multitude of nonspecific clinical symptoms mostly related to the anatomical location of the lesions. For example, the spectrum includes seizures, neuropsychiatric and focal symptoms. Other common clinical signs are attributed to increased intracranial pressure, including headache, nausea, vomiting, drowsiness and visual problems. In 
Fig. 1. Histopathological features of EBVassociated monomorphic B cell PTLD. a, b A diffuse infiltrate of transformed cells, partly with plasmacytic differentiation, including immunoblasts. The tumor has a high proliferation rate (MIB-1) approaching $80 \%$ (c) and abundant EBV positivity (d). Numerous CD10-positive (e) and CD79a-positive immunoblasts (f) are detectable in a typical perivascular arrangement.
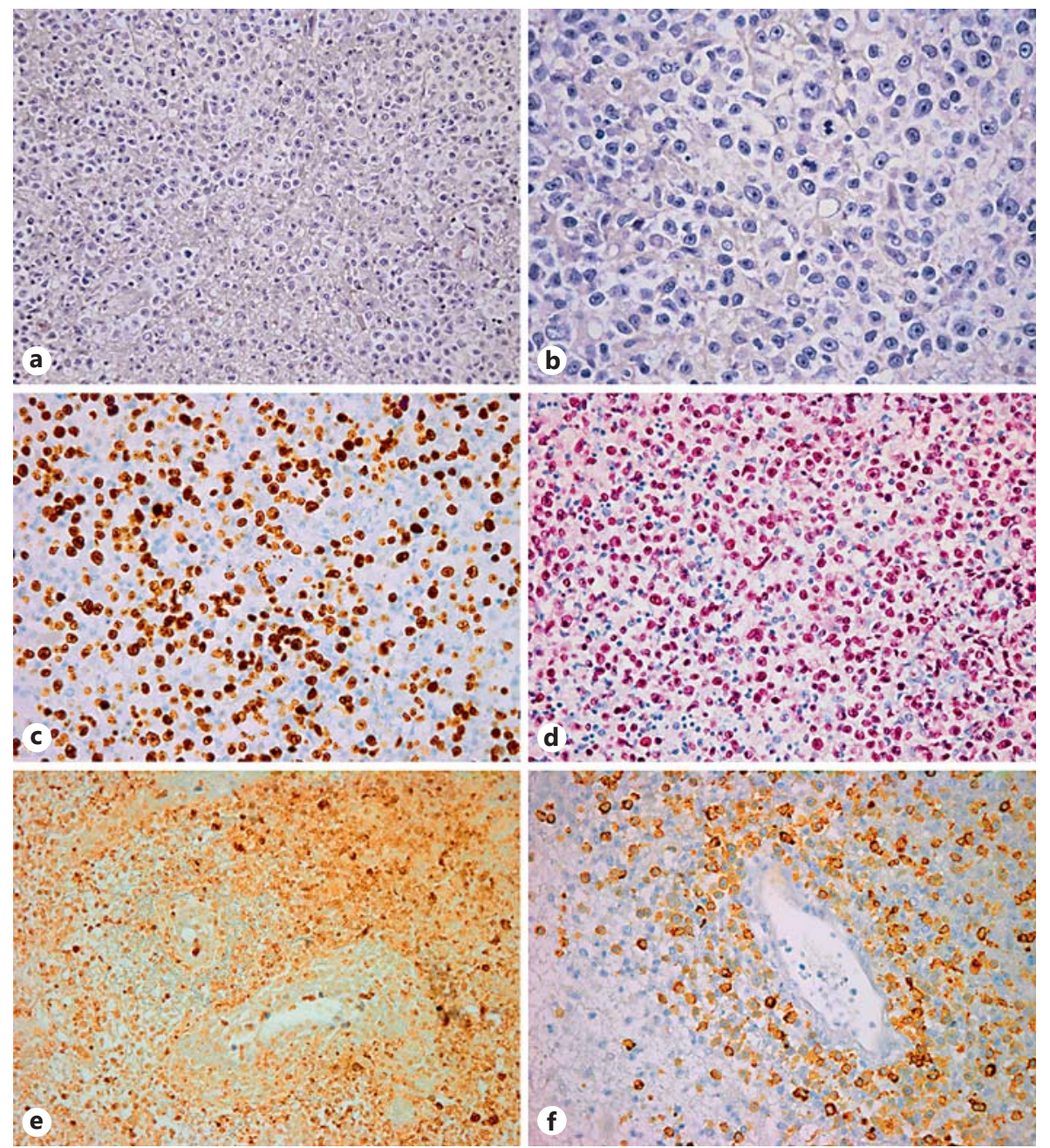

contrast to other lymphoid malignancies, fever and other constitutional symptoms are uncommon in cerebral PTLD [38].

\section{Imaging}

For the most part, the neuroradiographic features of PTLD are similar to those seen in immunocompromised individuals with primary CNS lymphoma. The most important radiological differential diagnosis in the posttransplant setting, which can show overlapping imaging features, is a CNS infection. In a study by Castellano-Sanchez et al. [6], 10 of 12 CNS PTLD patients presented with multiple, contrast-enhancing, intra-axial lesions with extensive edema and marked expansion of the perivascular spaces. Moreover, multicentric lesions are more frequent in CNS PTLD than in other primary CNS lymphomas. Specifically, these lesions characteristically appear in the deeper supratentorial structures, periventricular region, and less frequently in the cerebellum and brainstem. Manifestations in the spinal cord and leptomeninges have been rarely reported [39]. In the cranial MRI scan, PTLD masses appear hypointense to isointense on T1-weighted images. Areas of hyperintensity are thought to reflect the degree of intratumoral hemorrhage. Hypercellularity is reflected by hypointensity in T2-weighted images, whereas tumor necrosis leads to focal hyperintensities. The more diffuse distribution of both signals is sometimes helpful in distinguishing a lymphoproliferative disorders from an abscess, because abscess fluid typically shows a central region of hyperintensity in the immunosuppressed brain. Contrast enhancement may be homogeneous; however, unlike CNS lymphoma, ring enhancement is seen in most 
Fig. 2. Common immune signal expression pattern in monomorphic B cell PTLD. a Perivascular accumulation of CD20-positive $\mathrm{B}$ cells. The tissue displays partial expression of CD138 (syndecan-1)-positive plasmacytoid differentiated blasts (b). Focal BCL-2 expression mainly in immunoblasts (c) and sparsely distributed BCL-6 (d) immunopositivity is seen.
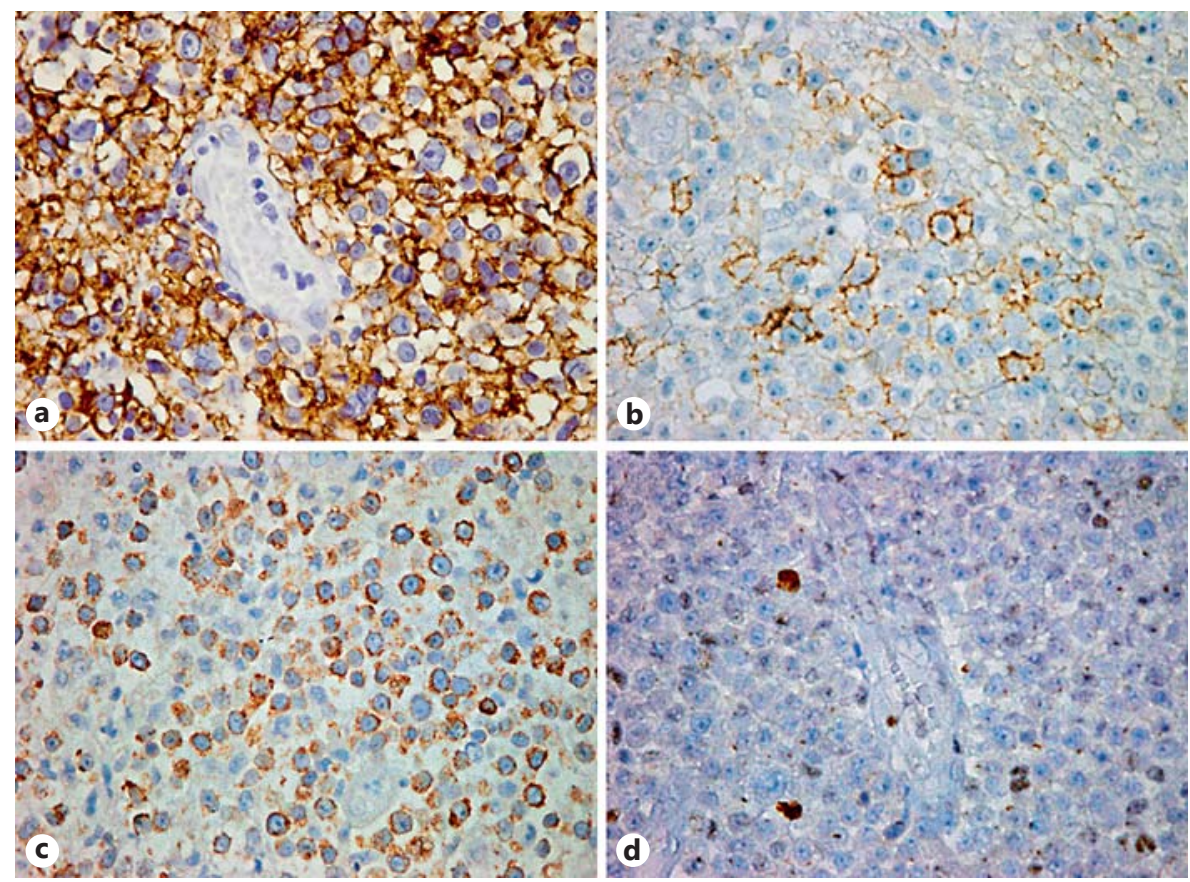

abscesses due to the presence of necrosis. Progressive multifocal leukoencephalopathy, another disorder seen in immunodeficient patients, is associated with only minimal or absent contrast enhancement. Besides toxoplasma encephalitis, fungal and viral infections have to be taken into consideration [40]. Even though all imaging features are nonspecific, when discovered in transplant recipients, the possibility of CNS PTLD has to be evaluated.

\section{Histopathological Diagnosis and Classification}

According to the World Health Organization (WHO) 2008 classification of lymphoid neoplasms [41], PTLD is defined as 'any lymphoid or plasmacytoid proliferation that develops in immunosuppressed recipients of solid organ, bone marrow, or stem cell allografts'. Three main pathological subsets/stages are recognized: early, polymorphic and monomorphic lesions (see table 1), which will be detailed below. According to their occurrence, PTLD is further categorized as either early-onset (within 1 year of the transplantation) or late-onset ( $>1$ year). EBV positivity is not required for the diagnosis of PTLD. Common characteristics encompass late onset and poorer response to therapy [3]. In addition, a less frequent nongerminal center phenotype with BCL- 6 expression and negative MUM-1/ IRF4 has been reported in EBV-negative examples [42].
Table 1. Categories of PTLD (WHO 2008)

1. Early lesions

a Reactive plasmacytic hyperplasia

b Infectious mononucleosis-like lesions

2. Polymorphic PTLD

3. Monomorphic PTLD

B cell neoplasms

a Diffuse large B cell lymphoma

b Burkitt's lymphoma

c Plasma cell myeloma

d Plasmacytoma-like lesions

e Others

T cell neoplasms

a Peripheral T cell lymphoma not otherwise specified

b Hepatosplenic T cell lymphoma

c Others

4. Classical Hodgkin's lymphoma-type and Hodgkin's lymphoma-like PTLD

\section{Histopathology and Immunoprofile of PTLD}

\section{Early Lesions}

Early lesions resemble reactive lymphoplasmacytic proliferations in immunocompetent hosts and lack destruction of the underlying tissue. These lesions include reactive plasmacytic hyperplasia and infectious mono- 
Table 2. Entity-specific features in the differential diagnosis of posttransplant lymphoproliferations

\begin{tabular}{|c|c|c|c|}
\hline Features & CNS PTLD & Primary CNS lymphoma & Other lesions of the immunosuppressed brain \\
\hline \multicolumn{4}{|c|}{ Clinical features } \\
\hline Age & $\begin{array}{l}\text { all ages, } 1-80 \text { years, median } 43.4 \text { years } \\
{[6]}\end{array}$ & $\begin{array}{l}\text { between the ages of } 45 \text { and } 70 \text { years, } \\
\text { median } 60 \text { years [ } 51]\end{array}$ & $\begin{array}{l}\text { all ages, more common in elderly, often no } \\
\text { convincing inflammatory/septic symptoms }\end{array}$ \\
\hline Manifestation & $\begin{array}{l}\text { symptoms and signs of raised intra- } \\
\text { cranial pressure, focal neurological } \\
\text { disorders }(75 \%[2]) \text { and seizures }\end{array}$ & $\begin{array}{l}\text { focal deficits, neuropsychiatric signs, } \\
\text { symptoms and signs of raised intracranial } \\
\text { pressure, seizures, ocular symptoms }\end{array}$ & $\begin{array}{l}\text { variable, from none to severe, depending on } \\
\text { localization } \\
\text { symptomatic only in immunocompromised } \\
\text { patients }\end{array}$ \\
\hline Latency & 3-131 months (mean 31 months) [6] & variable & variable, some remain latent infections \\
\hline Cofactors & $\begin{array}{l}\text { immunosuppression after transplan- } \\
\text { tation }\end{array}$ & congenital, HIV [49] & HIV, immunosuppression \\
\hline \multicolumn{4}{|c|}{ Radiological features } \\
\hline Lesion & multiple $>>$ single lesions $[2,6]$ & $65 \%$ solitary [49] & $\begin{array}{l}\text { scattered multifocal, edema and smaller } \\
\text { (toxoplasmosis) } \\
\text { single thin capsule (abscess) } \\
\text { incomplete, diffuse (demyelination) } \\
\text { multiple lesions in cortex (PML) }\end{array}$ \\
\hline Enhancement & $\begin{array}{l}\text { heterogeneous contrast enhancement } \\
{[2,6]}\end{array}$ & $\begin{array}{l}\text { homogeneous contrast enhancement, ring } \\
\text { enhancement reported in HIV patients [49] }\end{array}$ & $\begin{array}{l}\text { thick and nodular (neoplasm) } \\
\text { thin and regular (abscess) } \\
\text { incomplete ring (demyelination) } \\
\text { central targetoid, (toxoplasmosis) } \\
\text { none (PML), solid or ring-enhanced mass (TBC) }\end{array}$ \\
\hline Localization & $\begin{array}{l}81 \% \text { cerebral hemisphere } \\
\text { (cortex/white matter, basal ganglia, } \\
\text { corpus callosum), 15\% brainstem, } 4 \% \\
\text { cerebellum, spinal cord involvement } \\
\text { rare [6] }\end{array}$ & $\begin{array}{l}33 \% \text { cerebral hemisphere, } 16 \% \text { thalamus/ } \\
\text { basal ganglia, } 14 \% \text { corpus callosum, } 12 \% \\
\text { periventricular region, } 9 \% \text { cerebellum, } \\
\text { spinal cord involvement rare [49] }\end{array}$ & $\begin{array}{l}\text { basal ganglia, often bilateral, and corticomedul- } \\
\text { lary junction (toxoplasmosis) } \\
\text { larger lesions (Aspergillus) } \\
\text { subcortical hemisphere white matter (PML) } \\
\text { frontoparietal and basal ganglia (TBC) }\end{array}$ \\
\hline Edema & $\begin{array}{l}\text { extensive peritumoral edema com- } \\
\text { mon [6] }\end{array}$ & extensive peritumoral edema common [49] & $\begin{array}{l}\text { variable } \\
\text { mostly present (toxoplasmosis, abscess) } \\
\text { absent (PML) }\end{array}$ \\
\hline
\end{tabular}

Histopathological and molecular features

Infiltrate large, transformed cells with large, irregular nuclei, prominent nucleoli [6]
90-95\% of primary CNS lymphomas are diffuse, large B cell lymphomas: mostly large B cell type, immunoblasts and centroblasts $[49,50]$

\begin{tabular}{|c|c|}
\hline Growth pattern & $\begin{array}{l}\text { perivascular distribution, concentr } \\
\text { laminar growth pattern, transmura } \\
\text { invasion, sheet-like growth [6] }\end{array}$ \\
\hline Immune profile & 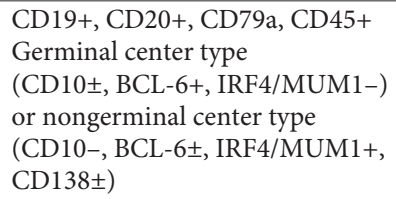 \\
\hline
\end{tabular}

characteristic lymphoid clustering around small cerebral vessels [49]

pan-B cell markers (CD20, CD19, CD22, CD79a), markers of germinal center B cell (BCL-6; 60-80\% of cases) and markers of late germinal center B cells (IRF4/MUM1; 90\%)

Rarely positive for CD10 (<10\%) [50]

$\mathrm{CD} 3+$ ( $\mathrm{T}$ cells), $\kappa$ and $\lambda$ light chains

(plasma cells), CD45+, CD15+ and CD30+ (large dysplastic cells)

\begin{tabular}{ll}
\hline Mitotic activity/MIB-1 & increased [1] \\
\hline Necrosis & very common $[2,6]$ \\
\hline EBV/other & $80 \%$ of all PTLD are positive for EBV \\
pathogens & most CNS cases are EBV+ mPTLD [2, \\
& $17] /$ HHV-8, simian virus 40, hepatitis \\
& C virus [17] \\
\hline Gene alterations & cMYC, BCL-6, TP53 [17]
\end{tabular}

increased [50]

negative for EBV [50]

CD95, cMYC13, PAX5, PIM1, PRDM114 and TTF [50] discrete multiple necrotizing lesions, (toxoplasmosis)

demyelination, macrophages, viral inclusions, lymphocytic inflammation (PML) surrounding epithelioid histiocytes, lymphocytes, plasma cells, multinucleated giant cells (Langerhans type), plasma cells (TBC)

multiple small cystic lesions, in periphery of necrotic areas, near blood vessel (toxoplasmosis)

toxoplasmosis +

SV-40+ (JC-virus, PML)

Grocott+ (Aspergillus)

Ziehl-Neelsen stain+ (Mycobacterium)

Streptococcus sp.+ (abscess) not increased variable

central caseation necrosis (TBC)

negative for EBV

Toxoplasma gondii

JC-virus

Aspergillus fumigatus/flavus, Staphylococcus

discussed

$\mathrm{PML}=$ Progressive multifocal leukoencephalopathy; $\mathrm{TBC}=$ tuberculosis. 
nucleosis-like PTLD which typically presents early after transplantation, usually appearing in the tonsils and lymph nodes [41].

\section{Polymorphic PTLD}

The hallmark of polymorphic PTLD is the presence of a mixed population of lymphoid and plasma cells. These tissue-destructive lymphoplasmacytic proliferations do not fulfill the criteria for a typical lymphoma as traditionally seen in immunocompetent patients. They show extensive cellular and maturational-stage polymorphism and the characteristic immunoprofile comprising variably sized $\mathrm{B}$ cell clones admixed with heterogeneous $\mathrm{T}$ cells. The infiltrates show an angiocentric localization and necrosis is seen in one third of the cases.

\section{Monomorphic PTLD}

Monomorphic PTLD (mPTLD) is defined as lesions containing numerous transformed lymphoid cells at one single maturational stage (see fig. 1). These may still show minimal pleomorphism and plasmacytic differentiation. The immune profile (see fig. 2) may either be that of a germinal center type (CD10 \pm , BCL-6+ and IRF4/MUM1-) or nongerminal center (CD10-, BCL-6 \pm , IRF4/MUM1+ and CD138 \pm ) [42].

The cardinal features of cerebral mPTLD are abundant aggregates of large, neoplastic lymphoid cells, harboring huge irregularly shaped nuclei with prominent nucleoli. These immunoblastic-like tumor cells are arranged in an angiocentric pattern with layers of neoplastic cells separated by concentric rings of reticulin fibers. A variable population of nonneoplastic T lymphocytes that diffusely infiltrate brain parenchyma is consistently present. The neoplastic B cells express CD19, CD20 and typically show immunopositivity for CD45 and EBV. Mitotic figures are common and, not surprisingly, the MIB-1 (Ki67) proliferation index is high. Monomorphic T cell PTLD in the CNS is extremely rare. Most reported cases share similar histopathological features that resemble systemic $\mathrm{T}$ cell lymphomas with infiltrates of small, monomorphic lymphocytes.

Of special mention, T cell PTLD appears much later than other PTLD types and two thirds of these not associated with EBV seropositivity [43]. Histologically, these entities often show necrosis and abundant, cytologically atypical lymphoid cells accompanied by reactive features that are sometimes indistinguishable from polymorphic PTLD. Immunohistochemistry with T cell markers is essential to confirm the diagnosis.

\section{Classical Hodgkin Lymphoma-Type PTLD}

To confirm the diagnosis of Hodgkin lymphoma-type PTLD, strict criteria must be fulfilled. These features include mixed cellularity, proliferations of small lymphocytes, plasma cells, histiocytes, eosinophils and ReedSternberg cells. Immunohistochemically, Reed-Sternberg cells are $\mathrm{CD} 15+, \mathrm{CD} 30+, \mathrm{PAX} 5+, \mathrm{CD} 20-, \mathrm{CD} 3-$ and CD45- and they are commonly surrounded by small $\mathrm{T}$ cell lymphocytes.

\section{Differential Diagnosis}

The recognition and accurate diagnosis of PTLD is of paramount importance for patient management. Procurement of a representative biopsy is the essential first step for histopathological and immunochemical examination. The limited size of biopsy specimens, sampling heterogeneity and crush artifact pose additional challenges to securing a firm diagnosis. Infectious disorders and other nonneoplastic lymphoproliferative disorders can sometimes mimic the histopathological features of PTLD (see table 2). As noted, diagnostic findings that argue for the diagnosis of PTLD are mass lesions composed of atypical lymphoid cells, numerous transformed cells, particularly B cell-rich infiltrates, extensive serpiginous necrosis and a high proportion of plasma cells and EBV-positive cells. Even distinguishing CNS PTLD from nontransplantation-associated primary CNS lymphomas is clinically relevant, as the prognosis and treatment strategies differ. Clearly, the clinical context defines the diagnostic considerations.

\section{Prognostic Factors for PTLD Progression}

Similar to non-Hodgkin lymphomas, patient age, multifocal disease and poor general performance (Karnovsky score) are associated with poor prognosis [44]. The rare $\mathrm{T}$ cell variant is known to have a worse prognosis [45]. Given the rarity of CNS PTLD patients, reliable information on prognostic factors is still missing.

\section{Treatment Modalities}

Despite the fact that PTLD is now a recognized complication of transplantation, no standard protocols exist for its prevention or treatment. Surgical resection is of no benefit and radiation therapy plays only a limited role in preventing cerebral herniation. Chemotherapy is the therapeutic mainstay and several new approaches have emerged over the last decade that are described in greater depth elsewhere [46]. Briefly, the therapeutic goal is to reduce the tumor burden with the lowest possible dose of 
immunosuppressive agents. As an example, dose reduction in cyclosporine-treated transplant patients has been shown to reverse the progression of PTLD [47].

Another promising therapeutic approach is monoclonal antibody therapy against CD20 + cells (rituximab) [48]. However, experience with this agent is still anecdotal in the setting of CNS PTLD and requires further study.

\section{Perspective and Conclusion}

The last decade has yielded considerable advances in understanding the pathophysiology of PTLD. However, the exact initiating pathomechanism that results in the failure of cytotoxic CD8+ T cells to contain EBV-infected $\mathrm{B}$ cell proliferation remains unresolved. Whether molecular changes are triggered by a single high dose of immunosuppressive therapy or result from cumulative effects is unclear. Other uncertainties include whether the disease onset and progression are directly related to the transplanted organ or are largely influenced by secondary factors such as the posttransplant therapeutic regime. Moreover, the nature and magnitude of the deleterious synergistic effects of combination therapy with immunosuppressive agents on the immune system mandates further investigation through multicenter clinical trials. Apart from these considerations, a fundamental question remains why only $10 \%$ of transplant recipients develop uncontrolled lymphoproliferation and what mechanisms underlie the different PTLD subtypes. Equally important is the early recognition and accurate diagnosis of this entity by clinicians and pathologists. Diagnostic problems may arise in distinguishing PTLD from infectious diseases and in patients treated with steroids prior to biopsy. Finally, therapeutic strategies need to be optimized and individualized according to evidence-based investigations.

\section{References}

1 Gibson T, Medawar PB: The fate of skin homografts in man. J Anat 1943;77:299-310.

2 Phan TG, O’Neill BP, Kurtin PJ: Posttransplant primary CNS lymphoma. Neuro Oncol 2000;2:229-238.

-3 Nelson BP, Nalesnik MA, Bahler DW, Locker J, Fung JJ, Swerdlow SH: Epstein-Barr virusnegative post-transplant lymphoproliferative disorders: a distinct entity? Am J Surg Pathol 2000;24:375-385.

-4 Yaginuma T, Yamamoto H, Mitome J, Tanno Y, Yamamoto I, Kobayashi A, Mafune A, Hayakawa H, Yokoyama K, Mori R, Ohashi H, Kaito N, Joki T, Miki J, Yamada H, Furuta N, Matsushima S, Fukuda T, Hosoya T: Successful treatment of monomorphic primary central nervous system post-transplantation lymphoproliferative disorder 5 years after kidney transplantation. Transpl Infect Dis 2012;14:E102-E106.

5 Dierickx D, Tousseyn T, De Wolf-Peeters C, Pirenne J, Verhoef G: Management of posttransplant lymphoproliferative disorders following solid organ transplant: an update. Leuk Lymphoma 2011;52:950-961.

6 Castellano-Sanchez AA, Li S, Qian J, Lagoo A, Weir E, Brat DJ: Primary central nervous system posttransplant lymphoproliferative disorders. Am J Clin Pathol 2004;121:246-253.

-7 Doak PB, Montgomerie JZ, North JDK, Smith F: Reticulum cell sarcoma after renal homotransplantation and azathioprine and prednisone therapy. Br Med J 1968;4:746-748.

8 Starzl TE: History of clinical transplantation. World J Surg 2000;24:759-782.
9 Schneck SA, Penn I: Cerebral neoplasms associated with renal transplantation. Arch Neurol 1970;22:226-233.

10 Armitage JM, Kormos RL, Stuart RS, Fricker FJ, Griffith BP, Nalesnik M, Hardesty RL, Dummer JS: Posttransplant lymphoproliferative disease in thoracic organ transplant patients: ten years of cyclosporine-based immunosuppression. J Heart Lung Transplant 1991;10:877-886.

11 Walker RC, Paya CV, Marshall WF, Strickler JG, Wiesner RH, Velosa JA, Habermann TM, Daly RC, McGregor CG: Pretransplantation seronegative Epstein-Barr virus status is the primary risk factor for posttransplantation lymphoproliferative disorder in adult heart, lung, and other solid organ transplantations. J Heart Lung Transplant 1995;14:214-221.

$\checkmark 12$ Cox KL, Lawrence-Miyasaki LS, Garcia-Kennedy R, Lennette ET, Martinez OM, Krams SM, Berquist WE, So SK, Esquivel CO: An increased incidence of Epstein-Barr virus infection and lymphoproliferative disorder in young children on FK506 after liver transplantation. Transplantation 1995;59:524529.

13 Pickhardt PJ, Siegel MJ, Hayashi RJ, Kelly M: Posttransplantation lymphoproliferative disorder in children: clinical, histopathologic, and imaging features. Radiology 2000;217: $16-25$.

-14 Mañez R, Breinig MC, Linden P, Wilson J, Torre-Cisneros J, Kusne S, Dummer S, Ho M: Posttransplant lymphoproliferative disease in primary Epstein-Barr virus infection after liv- er transplantation: the role of cytomegalovirus disease. J Infect Dis 1997;176:1462-1467.

15 Preiksaitis JK, Keay S: Diagnosis and management of posttransplant lymphoproliferative disorder in solid-organ transplant recipients. Clin Infect Dis 2001;33:S38-S46.

16 Cohen JI: Epstein-Barr virus Infection. N Engl J Med 2000;343:481-492.

17 Capello D, Gaidano G: Post-transplant lymphoproliferative disorders: role of viral infection, genetic lesions and antigen stimulation in the pathogenesis of the disease. Mediterr J Hematol Infect Dis 2009;1:e2009018.

18 Rea D, Fourcade C, Leblond V, Rowe M, Joab I, Edelman L, Bitker MO, Gandjbakhch I, Suberbielle C, Farcet JP, Raphael M: Patterns of Epstein-Barr virus latent and replicative gene expression in Epstein-Barr virus B cell lymphoproliferative disorders after organ transplantation. Transplantation 1994;58:317-324.

19 Randhawa PS, Jaffe R, Demetris AJ, Nalesnik M, Starzl TE, Chen YY, Weiss LM: Expression of Epstein-Barr virus-encoded small RNA (by the EBER-1 gene) in liver specimens from transplant recipients with post-transplantation lymphoproliferative disease. $\mathrm{N}$ Engl J Med 1992;327:1710-1714.

20 Küppers R: B cells under influence: transformation of $B$ cells by Epstein-Barr virus. Nat Rev Immunol 2003;3:801-812.

21 Tanner JE, Alfieri C: The Epstein-Barr virus and post-transplant lymphoproliferative disease: interplay of immunosuppression, EBV, and the immune system in disease pathogenesis. Transpl Infect Dis 2001;3:60-69. 
22 Young LS, Murray PG: Epstein-Barr virus and oncogenesis: from latent genes to tumours. Oncogene 2003;22:5108-5121.

23 Dalla-Favera R, Ye BH, Lo Coco F, Gaidano G, Lista F, Knowles DM, Louie DC, Offit K, Chaganti RS: Identification of genetic lesions associated with diffuse large-cell lymphoma. Ann Oncol 1994;5(suppl 1):55-60.

24 Basso K, Dalla-Favera R: BCL6:master regulator of the germinal center reaction and key oncogene in B cell lymphomagenesis. Adv Immunol 2010;105:193-210.

25 Vakiani E, Nandula SV, Subramaniyam S, Keller CE, Alobeid B, Murty VV, Bhagat G: Cytogenetic analysis of B-cell posttransplant lymphoproliferations validates the World Health Organization classification and suggests inclusion of florid follicular hyperplasia as a precursor lesion. Hum Pathol 2007;38: 315-325.

26 Knowles DM, Cesarman E, Chadburn A, Frizzera G, Chen J, Rose EA, Michler RE: Correlative morphologic and molecular genetic analysis demonstrates three distinct categories of posttransplantation lymphoproliferative disorders. Blood 1995;85:552-565.

27 Ibrahim HA, Naresh KN: Posttransplant lymphoproliferative disorders. Adv Hematol 2012;2012:230173.

28 de Alboran IM, O’Hagan RC, Gärtner F, Malynn B, Davidson L, Rickert R, Rajewsky K, DePinho RA, Alt FW: Analysis of c-MYC function in normal cells via conditional genetargeted mutation. Immunity 2001;14:45-55.

29 Poe JC, Minard-Colin V, Kountikov EI, Haas KM, Tedder TF: A c-MYC and surface CD19 signaling amplification loop promotes $\mathrm{B}$ cell lymphoma development and progression in mice. J Immunol 2012;189:2318-2325.

30 Yang X, Sham JS, Ng MH,,Tsao SW, Zhang D, Lowe SW, Cao L: LMP1 of Epstein-Barr virus induces proliferation of primary mouse embryonic fibroblasts and cooperatively transforms the cells with a p16-insensitive CDK4 oncogene. J Virol 2000;74:883-891.

- 31 Uchida J, Yasui T, Takaoka-Shichijo Y, Muraoka M, Kulwichit W, Raab-Traub N, Kikutani H: Mimicry of CD40 signals by EpsteinBarr virus LMP1 in B lymphocyte responses. Science 1999;286:300-303.
- 32 Gires O, Kohlhuber F, Kilger E, Baumann M, Kieser A, Kaiser C, Zeidler R, Scheffer B, Ueffing $M$, Hammerschmidt W: Latent membrane protein 1 of Epstein-Barr virus interacts with JAK3 and activates STAT proteins. EMBO J 1999;18:3064-3073.

33 Kulwichit W, Edwards RH, Davenport EM, Baskar JF, Godfrey V, Raab-Traub N: Expression of the Epstein-Barr virus latent membrane protein 1 induces $B$ cell lymphoma in transgenic mice. Proc Natl Acad Sci USA 1998;95:11963-11968.

34 Bialik S, Kimchi A: DAP-kinase as a target for drug design in cancer and diseases associated with accelerated cell death. Semin Cancer Biol 2004; 14:283-294.

35 Cyster JG, Goodnow CC: Antigen-induced exclusion from follicles and anergy are separate and complementary processes that influence peripheral B cell fate. Immunity 1995;3: 691-701.

- 36 Cerri M, Capello D, Muti G, Rambaldi A, Paulli M, Gloghini A, Berra E, Deambrogi C, Rossi D, Franceschetti S, Conconi A, Morra E, Pasqualucci L, Carbone A, Gaidano G: Aberrant somatic hypermutation in post-transplant lymphoproliferative disorders. $\mathrm{Br} \mathrm{J}$ Haematol 2004;127:362-364.

- 37 Gupta AK, Ruvolo V, Patterson C, Swaminathan S: The human herpesvirus 8 homolog of Epstein-Barr virus SM protein (KS-SM) is a posttranscriptional activator of gene expression. J Virol 2000;74:1038-1044.

38 Chou AP, Lalezari S, Fong BM, Dye J, Pham T, Vinters HV, Pouratian N: Post-transplantation primary central nervous system lymphoma: a case report and review of the literature. Surg Neurol Int 2011;2:130.

-39 Traum AZ, Rodig NM, Pilichowska ME, Somers MJ: Central nervous system lymphoproliferative disorder in pediatric kidney transplant recipients. Pediatr Transplant 2006;10:505-512.

40 Pickhardt PJ, Wippold FJ 2nd: Neuroimaging in posttransplantation lymphoproliferative disorder. AJR Am J Roentgenol 1999;172: $1117-1121$
41 Swerdlow SH, Campo E, Harris NL, Jaffe ES, Pileri SA, Stein H, Thiele J, Vardman JW (eds): WHO Classification of Tumors of Haematopoietic and Lymphoid Tissues. IARC, Lyon, 2008.

42 Johnson LR, Nalesnik MA, Swerdlow SH: Impact of Epstein-Barr virus in monomorphic B-cell posttransplant lymphoproliferative disorders: a histogenetic study. Am J Surg Pathol 2006;30:1604-1612.

43 Swerdlow SH: T-cell and NK-cell posttransplantation lymphoproliferative disorders. Am J Clin Pathol 2007;127:887-895.

44 Knight JS, Tsodikov A, Cibrik DM, Ross CW, Kaminski MS, Blayney DW: Lymphoma after solid organ transplantation: risk, response to therapy, and survival at a transplantation center. J Clin Oncol 2009;27:3354-3362.

45 Dotti G, Fiocchi R, Motta T, Mammana C, Gotti E, Riva S, Cornelli P, Gridelli B, Viero P, Oldani E, Ferrazzi P, Remuzzi G, Barbui T, Rambaldi A: Lymphomas occurring late after solid-organ transplantation: influence of treatment on the clinical outcome. Transplantation 2002;74:1095-1102.

46 Murukesan V, Mukherjee S: Managing posttransplant lymphoproliferative disorders in solid-organ transplant recipients: a review of immunosuppressant regimens. Drugs 2012; 72:1631-1643.

-47 Starzl TE, Nalesnik MA, Porter KA, Ho M Iwatsuki S, Griffith BP, Rosenthal JT, Hakala TR, Shaw BW Jr, Hardesty RL, et al: Reversibility of lymphomas and lymphoproliferative lesions developing under cyclosporine-steroid therapy. Lancet 1984;1:583-587.

48 Faye A, Van Den Abeele T, Peuchmaur M Mathieu-Boue A, Vilmer E: Anti-CD20 monoclonal antibody for post-transplant lymphoproliferative disorders. Lancet 1998; 352:1285.

49 Gerstner ER, Batchelor TT: Primary central nervous system lymphoma. Arch Neurol 2010;67:291-297.

50 Ferreri AJ, Marturano E: Primary CNS lymphoma. Best Pract Res Clin Haematol 2012; 25:119-130.

51 Mohile NA, Abrey LE: Primary central nervous system lymphoma. Neurol Clin 2007;25: 1193-1207. 